\title{
Credit Rating Changes and Subordinated Bond Spread: Evidence from China
}

\author{
Robin Hang Luo (Corresponding author) \\ Dept. of Accounting \& Finance, Faculty of Business, ALHOSN University \\ PO Box 38772, Abu Dhabi, UAE \\ Tel: 971-2-4070-522Ｅ-mail: h.luo@alhosnu.ae
}

Jiaji Hao

Dept. of Research \& Development, Moody's Affiliate - CCXI

156 Fuxingmennei Ave, Xicheng, Beijing 100031, China

Tel: 86-10-6642-8877Ｅ-mail: jjhao@ccxi.com.cn

\begin{abstract}
Received: September 22, 2014 Accepted: October 17, $2014 \quad$ Published: March 30, 2014
doi:10.5296/ifb.v2i1.7548 URL: http://dx.doi.org/10.5296/ifb.v2i1. 7548
\end{abstract}

\begin{abstract}
We examine the bond spread reaction to subordinated bond rating changes during the sample period of 2006 to 2011 and find that bond spread reacted positively to downgrades, big in magnitude, but not statistically significant. The bond spread reaction to upgrades, however, was mixed and statistically insignificant, and small in magnitude. We conjecture that the insignificant statistical results regarding the effect of rating changes may be due to the lack of informational content of the ratings assigned to the subordinated bonds by Chinese credit rating agencies (CRAs).
\end{abstract}

Keywords: Credit rating changes, Subordinated bond, Spread, China 


\section{Introduction}

The January 2013 deadline for the Basel III reforms has led to a rush by Chinese banks to expand their capital base. Unless banks unload their subordinated debt, any new issue from 2013 onwards will be subject to the new and tougher regulations on subordinated debt. Banks will bear higher costs from issuing subordinated debentures when Basel III is implemented on January 1 because the new standard requires subordinated debt, which is part of Tier 2 capital, not to offer redemption incentives or issue step-ups to buyers.

The rules have prompted banks including the Big Four state-owned banks, to speed-up their debt issuance plans. Under Basel III, funds raised by banks through subordinated bonds won't be counted as part of their capital base, unless investors are willing to write down the value of the debt entirely or allow the bonds to be converted into shares. This means sub-debt investors, more often domestic financial institutions and insurers who prefer to be ranked above ordinary shareholders in case of a default, will have to reconsider their risk-assessment models when making such investments.

Actually, China's commercial banks have scrambled to issue subordinated bonds in order to replenish their capital base amid sluggish performances in the capital market since 2008 . The amount of subordinated bonds issued by commercial banks totaled 330 billion yuan (52.4 billion U.S. dollars) in 2011. Apart from the top 4 state-owned banks, medium- and small-sized banks have also joined the issuing boom to shore up their capital base.

In this scenario, it becomes more important to understand the credit rating mechanism on the subordinated bonds issued in China and how the rating changes affect the bond spread of subordinated debt. In the present study, we examine the market reactions to bond rating announcements on subordinated bonds in the period of 2006-2011. We focus on the bond yield effects following the rating change announcements, and examine how the effects differ across upgrades and downgrades. This study contributes to the literature in four aspects. First, the study is the first study on credit ratings and market reactions on subordinated bonds for China. Second, one advantage of our study is the use of daily data to isolate the announcement effect on bond yield. We endeavor to exclude concurrent disclosure from other known sources to provide a cleaner picture about the information content of credit ratings in China, though this effect can be comprised by the paucity of trading data. Third, we further the previous studies by looking at the problems and prospects of the most recent development in credit ratings in China to assess the development stages of credit ratings and the markets, shedding light on the transitional nature of market institutions in China. An exploration of these issues would have public policy implications for shaping a sound financial market that meets financing needs of the corporate sector.

The article proceeds as follows. Section 2 reviews the credit rating literature. Section 3 describes the data and summary statistics and displays the model and empirical results. Section 4 discusses problems and prospects of the most recent development in credit rating industry in China. Concluding remarks are in Section 5.

\section{Literature Review}

Credit ratings, as a source of information about creditworthiness of issuers (Sinclair, 2014), 
provide investors with the likelihood of whether their investment will not yield the promised return. Many researchers have been devoted to examine how the uncertainty of debt creditworthiness affects both the stock and debt values of the firm. The results that have been produced are mixed. The first line of studies has shown that a firm's debt uncertainty measures signaled by credit ratings affect its stock. Empirical studies generally provide evidence supporting the signaling hypothesis that credit ratings convey other than public information with regard to creditworthiness of issuers to investors. Numerous studies find that the stock market reacts negatively and significantly to bond rating downgrades but not to upgrades (Griffin \& Sanvicente, 1982; Holthausen \& Leftwich, 1986; Hand et al., 1992; Goh \& Ederington, 1993, 1999; Ederington \& Goh, 1998; Norden \& Weber, 2004; Li et al., 2006; Kim \& Nabar, 2007). Some studies argue that the market reacts more negatively to the downgrade announcements within the speculative bond category than within the investment grade category (Hand et al., 1992; Kliger \& Sarig, 2000). Dichev and Piotroski (2001), Jorion et al. (2005), and Jorion and Zhang (2007) find statistically significant stock price responses to both downgrades and upgrades.

The second line of studies focuses on the link between debt and bond value uncertainties. Bond upgrades and downgrades exert different effects on excess bond return. Monthly changes in bond yields (Katz, 1974), average monthly bond prices (Grier \& Katz, 1976) and monthly changes in municipal bond yields (Ingram et al., 1983) present significant reaction to rating change announcements, supporting the hypothesis that a better bond rating or a bond rating upgrade reflects lower debt value uncertainty, and vice versa. However, using monthly corporate bond returns, Weinstein (1977) and Wansley and Clauretie (1985) do not find significant reactions to downgrades or upgrades in the month of and month following a rating change, providing no support for the argument that credit ratings reveal the private information of firms to investors. The majority of the evidence on price effects rating announcements in corporate bond ratings is documented based on the US credit ratings, given the dominance of Moody's, Standard \& Poor and Fitch in the global market. Few efforts has been put to examine how far bond and stock markets react to the rating announcements in other economies and especially in emerging markets, such as China, where the market and institutional framework distinctly differ from those of mature economies, leaving the emerging markets less understood and the literature less representative.

Several qualitative studies have looked at the recent development of credit ratings in China and heavily criticize that the lack of creditability and independence in credit rating exercise and question the role that credit ratings play in reducing informational asymmetries and the relevance of ratings to investors (Bottelier, 2003; Kennedy, 2003). In a related study, Poon and Chan (2008) is the first among them to conduct a quantitative analysis on credit ratings and their impact on stock returns. Poon and Chan (2008) identify the certification and signaling effects, and concludes that credit ratings assigned by the domestic rating agency can generate information effects and that the market is efficient enough to react to the news. Although the study provides valuable information on the market efficiency associated with credit ratings in China, the implication is limited in a number of ways. The study does not exclude contaminated information that is concurrently announced from other known sources, leading to the questioning of validity of the conclusion that the responses in the stock markets 
are as a result of the rating announcement and changes. The study pools all bond issues together, without considering differential price effects that bond issues with different maturities may have. The study covers the period of 2002-2006, and so the implication is only confined to the early stage of credit ratings industry in China. Consequently, whether and to what extent rating changes bring new information to financial markets, especially bond markets in China, is a question unresolved by the literature.

\section{Model and Empirical Result}

We use the transaction data and rating changes from Bankscope, WIND and China Chengxin International Credit Rating Co., Ltd. (CCXI). CCXI was licensed by the People's Bank of China and the Ministry of Commerce in 1987 and is the first Sino-foreign joint venture which was set up in 2006 between Moody's and its parent company, with Moody's holding 49\% stake in CCXI and having an option to increase its ownership over time as permitted by Chinese authorities (Note 1).

Table 1 reports the name and ticker of 23 Chinese commercial banks who issued subordinated bonds between 2006 and 2011. This table also shows the total assets of these banks by the end of 2011 and relevant country rank and world rank based on their total assets. Affected by the huge credit scale, the capital adequacy ratios of all Chinese banks declined sharply in the past few years. The capital adequacy ratios in some banks were even lower than 8 percent before 2009. Under heavy pressure, all banks, especially medium- and small- size banks had to attempt all means to raise capital. They showed special interest in subordinated bonds although it is not the only way to raise funds.

Table 1. Chinese banks who issue the subordinated bonds with rating changes

\begin{tabular}{|l|c|c|c|c|}
\hline Bank Name & Ticker & $\begin{array}{c}\text { Country Rank } \\
\text { by Assets }\end{array}$ & $\begin{array}{c}\text { World Rank } \\
\text { by Assets }\end{array}$ & $\begin{array}{c}\text { Total Assets } \\
\text { (million USD) }\end{array}$ \\
\hline China Merchants Bank & CMB & 9 & 86 & 362,758 \\
\hline Shanghai Pudong Development Bank & SPDB & 10 & 92 & 330,884 \\
\hline China CITIC Bank & CITICB & 11 & 100 & 314,260 \\
\hline Industrial Bank & IB & 12 & 112 & 279,284 \\
\hline China Everbright Bank & CEB & 14 & 129 & 223,457 \\
\hline Hua Xia Bank & HXB & 15 & 164 & 157,081 \\
\hline China Guangfa Bank & GFB & 16 & 195 & 122,966 \\
\hline Bank of Beijing & BJB & 17 & 208 & 110,708 \\
\hline Shenzhen Development Bank & SDB & 18 & 209 & 109,863 \\
\hline Bank of Shanghai & SHB & 19 & 251 & 85,578 \\
\hline Bank of Jiangsu & JSB & 20 & 310 & 64,995 \\
\hline Evergrowing Bank & EB & 23 & 474 & 41,389 \\
\hline Bank of Ningbo & NBB & 25 & 489 & 39,752 \\
\hline Shanghai Rural Commercial Bank & SRCB & 27 & 512 & 37,949 \\
\hline Bank of Nanjing & NJB & 28 & 552 & 33,443 \\
\hline
\end{tabular}




\begin{tabular}{|l|c|c|c|c|}
\hline Bank of Hangzhou & HZB & 29 & 559 & 32,830 \\
\hline China Zheshang Bank & CZB & 30 & 560 & 32,812 \\
\hline Bank of Dalian & DLB & 35 & 674 & 26,085 \\
\hline Harbin Bank & HRB & 42 & 829 & 19,902 \\
\hline Shengjing Bank & SJB & 45 & 893 & 16,604 \\
\hline Bank of Dongguan & DGB & 47 & 914 & 16,256 \\
\hline Bank of Zhengzhou & ZZB & 91 & 2110 & 4,160 \\
\hline Bank of Deyang & DYB & 110 & 3273 & 1,841 \\
\hline
\end{tabular}

Source: Bankscope.

We use WIND to identify rating changes by the CCXI, Lianhe and Dagong between 2006 and 2011. We are able to obtain the ratings history and necessary bond characteristics data (e.g. maturity, coupon rate, etc.) from WIND. At the issue level, the imposition of these screens results in a preliminary sample of 41 bond rating changes ( 2 downgrades and 39 upgrades). However, trading activity around rating changes illustrates the illiquidity of the subordinated bond market in China. 19 issue level observations mentioned above trade on fewer than fourteen days during the 201 market days centered around Day 0 (Day -100 to +100 ), where Day 0 is the rating change data, or do not trade at all. To deal with this illiquidity, we impose trading restrictions. For all our analyses of daily spread, we require a bond to trade on at least 10 days during Day -30 to +30 . This screen is similar to the one employed by Bessembinder et al. (2009). Table 2 reports the preliminary sample of 41 bond rating changes. Table 3 reports the screened sample of 22 bond rating changes.

Table 2. Preliminary sample of 41 rating changes

\begin{tabular}{|l|c|c|c|c|c|}
\hline Bond & $\begin{array}{c}\text { Latest rating } \\
\text { announcement date }\end{array}$ & $\begin{array}{c}\text { Latest } \\
\text { rating }\end{array}$ & $\begin{array}{c}\text { Adjust } \\
\text { ment }\end{array}$ & $\begin{array}{c}\text { Previous rating } \\
\text { announcement Date }\end{array}$ & $\begin{array}{c}\text { Previous } \\
\text { rating }\end{array}$ \\
\hline 05NJB01 & $2011 / 7 / 27$ & AA & Up & $2010 / 7 / 28$ & AA- \\
\hline 06CMBC01 & $2007 / 7 / 30$ & AA & Down & $2006 / 7 / 28$ & AAA \\
\hline 06CMBC01 & $2008 / 7 / 24$ & AA + & Up & $2007 / 7 / 30$ & AA \\
\hline 06CITICB01 & $2010 / 7 / 27$ & AAA & Up & $2009 / 11 / 10$ & AA+ \\
\hline 06CITICB02 & $2010 / 7 / 27$ & AAA & Up & $2009 / 11 / 10$ & AA+ \\
\hline 06CZB & $2011 / 6 / 26$ & AA- & Up & $2010 / 7 / 20$ & A+ \\
\hline 06CZB & $2007 / 7 / 31$ & A+ & Down & $2006 / 4 / 30$ & AA- \\
\hline 06CZB & $2008 / 1 / 15$ & A & Up & $2007 / 7 / 27$ & A- \\
\hline 06CZB & $2009 / 4 / 22$ & A+ & Up & $2008 / 6 / 26$ & A \\
\hline 06CZB & $2010 / 11 / 17$ & AA- & Up & $2010 / 7 / 27$ & AA- \\
\hline 06CZB & $2011 / 7 / 15$ & AA & Up & $2010 / 11 / 17$ & AA- \\
\hline 06IB02.FX & $2010 / 3 / 30$ & AA & Up & $2009 / 11 / 4$ & AA- \\
\hline 06IB02.FL & $2010 / 3 / 30$ & AA & Up & $2009 / 11 / 4$ & AA- \\
\hline 06HZB01 & $2011 / 7 / 27$ & AA & Up & $2010 / 7 / 28$ & \\
\hline
\end{tabular}




\begin{tabular}{|c|c|c|c|c|c|}
\hline 07HXB01.FX & $2010 / 3 / 30$ & $\mathrm{AA}$ & $\mathrm{Up}$ & $2009 / 11 / 4$ & AA- \\
\hline 07HXB01.FL & $2010 / 3 / 30$ & $\mathrm{AA}$ & $\mathrm{Up}$ & $2009 / 11 / 4$ & AA- \\
\hline 07DGB01 & $2012 / 7 / 16$ & AA- & $\mathrm{Up}$ & $2011 / 6 / 13$ & $\mathrm{~A}+$ \\
\hline 07SPDB02 & $2010 / 6 / 25$ & $\mathrm{AA}+$ & $\mathrm{Up}$ & $2009 / 7 / 21$ & $\mathrm{AA}$ \\
\hline 07SPDB01 & $2010 / 6 / 25$ & $\mathrm{AA}+$ & $\mathrm{Up}$ & $2009 / 7 / 21$ & $\mathrm{AA}$ \\
\hline 08SDB.FX & $2011 / 7 / 26$ & $\mathrm{AA}+$ & $\mathrm{Up}$ & $2010 / 7 / 1$ & $\mathrm{AA}$ \\
\hline 08SDB.FL & $2011 / 7 / 26$ & $\mathrm{AA}+$ & $\mathrm{Up}$ & $2010 / 7 / 1$ & $\mathrm{AA}$ \\
\hline 08SDB02 & $2011 / 7 / 26$ & $\mathrm{AA}+$ & Up & $2010 / 7 / 1$ & AA \\
\hline 08CEB01.FX & $2008 / 10 / 13$ & $\mathrm{AA}+$ & $\mathrm{Up}$ & $2008 / 4 / 9$ & $\mathrm{AA}$ \\
\hline 08CEB.FL & $2008 / 10 / 13$ & $\mathrm{AA}+$ & Up & $2008 / 4 / 9$ & $\mathrm{AA}$ \\
\hline 08CEB02.FX & $2008 / 10 / 13$ & $\mathrm{AA}+$ & Up & $2008 / 4 / 9$ & AA \\
\hline 08GFB.FL & $2010 / 7 / 29$ & $\mathrm{AA}+$ & Up & 2009/7/17 & AA \\
\hline 08GFB01.FX & $2010 / 7 / 29$ & $\mathrm{AA}+$ & $\mathrm{Up}$ & $2009 / 7 / 17$ & $\mathrm{AA}$ \\
\hline 08GFB02.FX & $2010 / 7 / 29$ & $\mathrm{AA}+$ & Up & $2009 / 7 / 17$ & AA \\
\hline 08JSB01 & $2011 / 6 / 17$ & $\mathrm{AA}$ & $\mathrm{Up}$ & $2010 / 7 / 29$ & AA- \\
\hline 08JSB02 & $2011 / 6 / 17$ & AA & $\mathrm{Up}$ & $2010 / 7 / 29$ & AA- \\
\hline 08BJB01 & $2010 / 7 / 15$ & AAA & $\mathrm{Up}$ & $2009 / 7 / 20$ & $\mathrm{AA}+$ \\
\hline 08BJB01 & $2009 / 7 / 20$ & $\mathrm{AA}+$ & Up & $2008 / 7 / 2$ & AA \\
\hline 08BJB02 & $2009 / 7 / 20$ & $\mathrm{AA}+$ & Up & $2008 / 7 / 2$ & AA \\
\hline 08BJB02 & $2010 / 7 / 15$ & AAA & $\mathrm{Up}$ & $2009 / 7 / 20$ & $\mathrm{AA}+$ \\
\hline 08SJB & $2009 / 8 / 20$ & $\mathrm{~A}+$ & $\mathrm{Up}$ & $2008 / 7 / 24$ & A \\
\hline 08SJB & $2012 / 7 / 24$ & AA- & $\mathrm{Up}$ & $2011 / 7 / 29$ & $\mathrm{~A}+$ \\
\hline 08HZB & $2011 / 7 / 27$ & $\mathrm{AA}$ & $\mathrm{Up}$ & $2010 / 7 / 28$ & AA- \\
\hline 09EB & $2012 / 7 / 12$ & $\mathrm{AA}$ & $\mathrm{Up}$ & $2011 / 5 / 23$ & AA- \\
\hline 09SDB01 & $2011 / 4 / 6$ & $\mathrm{AA}$ & Up & $2010 / 10 / 29$ & AA- \\
\hline 09CZB & $2011 / 7 / 15$ & $\mathrm{AA}$ & Up & $2010 / 11 / 17$ & AA- \\
\hline 09CZB & $2010 / 11 / 17$ & AA- & $\mathrm{Up}$ & $2010 / 7 / 27$ & $\mathrm{~A}+$ \\
\hline 09NBB & $2011 / 7 / 27$ & $\mathrm{AA}+$ & $\mathrm{Up}$ & $2010 / 7 / 29$ & AA \\
\hline 09DYB & $2012 / 6 / 26$ & A- & $\mathrm{Up}$ & $2011 / 7 / 28$ & $\mathrm{BBB}+$ \\
\hline 09JSB & $2011 / 6 / 17$ & $\mathrm{AA}$ & $\mathrm{Up}$ & $2010 / 7 / 29$ & AA- \\
\hline 09SHB01 & $2012 / 7 / 10$ & AAA & $\mathrm{Up}$ & $2011 / 7 / 5$ & $\mathrm{AA}+$ \\
\hline 09SHB02 & $2012 / 7 / 10$ & AAA & $\mathrm{Up}$ & $2011 / 7 / 5$ & $\mathrm{AA}+$ \\
\hline 09SRCB & $2010 / 5 / 28$ & AA- & $\mathrm{Up}$ & $2009 / 4 / 27$ & $\mathrm{~A}+$ \\
\hline 09SRCB & $2012 / 6 / 27$ & $\mathrm{AA}$ & $\mathrm{Up}$ & $2011 / 6 / 13$ & AA- \\
\hline 09HRB & $2012 / 7 / 27$ & $\mathrm{AA}$ & $\mathrm{Up}$ & $2011 / 7 / 27$ & AA- \\
\hline 09HRB & $2011 / 7 / 27$ & AA- & $\mathrm{Up}$ & $2010 / 7 / 29$ & $\mathrm{~A}+$ \\
\hline 09DLB & $2011 / 4 / 29$ & AA- & Up & $2010 / 7 / 23$ & $\mathrm{~A}+$ \\
\hline 09ZZB & $2012 / 4 / 27$ & AA- & Up & $2011 / 7 / 18$ & A \\
\hline
\end{tabular}

Source: WIND. 
Table 3. Screened sample of 21 rating changes

\begin{tabular}{|l|c|c|c|c|c|}
\hline Bond & $\begin{array}{c}\text { Latest rating } \\
\text { announcement date }\end{array}$ & $\begin{array}{c}\text { Latest } \\
\text { rating }\end{array}$ & $\begin{array}{c}\text { Adjust } \\
\text { ment }\end{array}$ & $\begin{array}{c}\text { Previous rating } \\
\text { announcement Date }\end{array}$ & $\begin{array}{c}\text { Previous } \\
\text { rating }\end{array}$ \\
\hline 05NJB01 & $2011 / 7 / 27$ & AA & Up & $2010 / 7 / 28$ & AA- \\
\hline 06CMBC01 & $2007 / 7 / 30$ & AA & Down & $2006 / 7 / 28$ & AAA \\
\hline 06CMBC01 & $2008 / 7 / 24$ & AA+ & Up & $2007 / 7 / 30$ & AA \\
\hline 07HXB01.FL & $2010 / 3 / 30$ & AA & Up & $2009 / 11 / 4$ & AA- \\
\hline 08SDB.FX & $2011 / 7 / 26$ & AA+ & Up & $2010 / 7 / 1$ & AA \\
\hline 08SDB.FL & $2011 / 7 / 26$ & AA+ & Up & $2010 / 7 / 1$ & AA \\
\hline 08CEB01.FX & $2008 / 10 / 13$ & AA+ & Up & $2008 / 4 / 9$ & AA \\
\hline 08GFB01.FX & $2010 / 7 / 29$ & AA+ & Up & $2009 / 7 / 17$ & AA \\
\hline 08GFB02.FX & $2010 / 7 / 29$ & AA+ & Up & $2009 / 7 / 17$ & AA \\
\hline 08BJB01 & $2009 / 7 / 20$ & AA+ & Up & $2008 / 7 / 2$ & AA \\
\hline 08BJB02 & $2009 / 7 / 20$ & AA+ & Up & $2008 / 7 / 2$ & AA \\
\hline 08BJB02 & $2010 / 7 / 15$ & AAA & Up & $2009 / 7 / 20$ & AA+ \\
\hline 08SJB & $2012 / 7 / 24$ & AA- & Up & $2011 / 7 / 29$ & A+ \\
\hline 08HZB & $2011 / 7 / 27$ & AA & Up & $2010 / 7 / 28$ & AA- \\
\hline 09CZB & $2011 / 7 / 15$ & AA & Up & $2010 / 11 / 17$ & AA- \\
\hline 09CZB & $2010 / 11 / 17$ & AA- & Up & $2010 / 7 / 27$ & A+ \\
\hline 09NBB & $2011 / 7 / 27$ & AA+ & Up & $2010 / 7 / 29$ & AA \\
\hline 09SRCB & $2010 / 5 / 28$ & AA- & Up & $2009 / 4 / 27$ & A+ \\
\hline 09SRCB & $2012 / 6 / 27$ & AA & Up & $2011 / 6 / 13$ & AA- \\
\hline 09HRB & $2012 / 7 / 27$ & AA & Up & $2011 / 7 / 27$ & AA- \\
\hline 09HRB & $2011 / 7 / 27$ & AA- & Up & $2010 / 7 / 29$ & A+ \\
\hline 09DLB & $2011 / 4 / 29$ & AA- & Up & $2010 / 7 / 23$ & A+ \\
\hline 09ZZB & $2012 / 4 / 27$ & AA- & Up & $2011 / 7 / 18$ & A \\
\hline
\end{tabular}

Source: WIND.

We compute daily raw returns on individual bond issues following Bessembinder et al. (2009) and May (2010):

$$
\text { Bond } \operatorname{Re} \text { turn }_{\text {raw }}=\frac{P_{t}-P_{t-1}+A I_{t}}{P_{t-1}}
$$

Where $P_{t}$ and $P_{t-1}$ are the daily prices on days $t$ and $t-1$, respectively, and $A I_{t}$ is the interest accrued over day $t$. The accrued interest on day $t$ is computed as the annual coupon payment multiplied by $L$, all divided by 360 , where $L$ is the number of calendar days elapsed between the close of day $t-1$ and day $t$. If the bond is not traded on day $t$, $P_{t}$ is set equal to the most recent observed daily price. 
We then compute the daily bond spread as the raw return minus the bench market rate:

$$
B S_{t}=R_{t}-B R_{t}
$$

Where on day $t, B S_{t}$ is the spread of subordinated bonds, $R_{t}$ is the raw bond return, and $B R_{t}$ is the yield to maturity of the government bond.

Table 4. Empirical results on bond spread reaction

\begin{tabular}{|c|c|c|c|c|c|c|}
\hline Bond & $\begin{array}{c}\text { Latest rating } \\
\text { announcement } \\
\text { date }\end{array}$ & $\begin{array}{c}\text { Adjustm } \\
\text { ent }\end{array}$ & $\begin{array}{c}\text { Trading } \\
\text { before/after } \\
\text { the event } \\
\text { window } \\
(-1,+1)\end{array}$ & $\begin{array}{c}\text { Bond spread } \\
\text { before/after } \\
\text { the event } \\
\text { window } \\
(-1,+1)(\%)\end{array}$ & $\begin{array}{c}\text { Trading } \\
\text { before/after } \\
\text { the event } \\
\text { window } \\
(-30,+30)\end{array}$ & $\begin{array}{c}\text { Bond spread } \\
\text { before/after the } \\
\text { event window } \\
(-30,+30)(\%)\end{array}$ \\
\hline 05NJB01 & $2011-07-27$ & $\mathrm{Up}$ & No & -0.25 & Yes & -0.31 \\
\hline 06CMBC01 & $2008-07-24$ & $\mathrm{Up}$ & Yes & -0.11 & Yes & -0.17 \\
\hline 06CMBC01 & $2007-07-30$ & Down & No & 1.99 & Yes & 1.42 \\
\hline 07HXB01.FL & $2010-03-30$ & $\mathrm{Up}$ & No & 0.00 & No & -0.21 \\
\hline 08SDB.FX & $2011-07-26$ & $\mathrm{Up}$ & Yes & 0.16 & Yes & 0.19 \\
\hline 08SDB.FL & $2011-07-26$ & $\mathrm{Up}$ & No & 1.07 & No & 1.07 \\
\hline 08CEB01.FX & $2008-10-13$ & $\mathrm{Up}$ & No & 0.40 & No & 0.40 \\
\hline 08GFB01.FX & $2010-07-29$ & $\mathrm{Up}$ & No & 0.02 & Yes & -0.20 \\
\hline 08GFB02.FX & $2010-07-29$ & $\mathrm{Up}$ & Yes & 0.15 & Yes & 0.24 \\
\hline 08BJB01 & $2009-07-20$ & $\mathrm{Up}$ & No & 0.17 & Yes & -0.80 \\
\hline 08BJB02 & $2010-07-15$ & $\mathrm{Up}$ & No & 0.59 & Yes & 0.51 \\
\hline 08BJB02 & $2010-07-15$ & $\mathrm{Up}$ & No & -0.64 & Yes & -0.05 \\
\hline 08SJB & $2009-08-20$ & $\mathrm{Up}$ & No & 0.48 & Yes & -0.16 \\
\hline 08HZB & $2011-07-27$ & $\mathrm{Up}$ & No & 0.16 & Yes & 0.32 \\
\hline 09CZB & $2011-07-15$ & $\mathrm{Up}$ & No & -0.37 & No & -0.32 \\
\hline 09CZB & $2010-11-17$ & $\mathrm{Up}$ & No & -0.43 & No & -0.43 \\
\hline 09NBB & $2011-07-27$ & $\mathrm{Up}$ & No & 0.39 & Yes & 3.33 \\
\hline 09HRB & $2011-07-27$ & $\mathrm{Up}$ & No & 0.04 & Yes & 0.04 \\
\hline 09DLB & $2011-04-29$ & $\mathrm{Up}$ & No & -0.30 & No & -0.30 \\
\hline 09ZZB & $2012-04-27$ & $\mathrm{Up}$ & No & -0.19 & Yes & -0.39 \\
\hline 09SRCB & $2012-06-27$ & $\mathrm{Up}$ & No & -0.05 & Yes & -0.62 \\
\hline 09SRCB & $2010-05-28$ & $\mathrm{Up}$ & No & 0.13 & Yes & 0.25 \\
\hline & & & & & & \\
\hline
\end{tabular}

Table 4 reports the bond spreads for the full samples of downgrades and upgrades. It suggests that downgrade has a significant effect on bond spread though there was only one downgrade 
case. The downgraded bank experiences a huge increase on the bond spread in both the event windows $(-1,+1)$ and $(-30,+30)$. Holthausen and Leftwich (1986) and Goh and Ederington (1993) document a similar result on the abnormal bond returns for the common stock of downgraded firms. However, the bond spread of upgraded subordinated bonds either increases or decreases in both event windows. This evidence suggests that the information conveyed by an upgrade may not be fully incorporated into bond spread.

For each event window, we report a t-statistic based on the cross-sectional standard error of bond spreads to examine whether the median bond spread differs from zero. The results in Table 5 suggest that both upgrades and downgrades of the subordinated bonds in China do not have a significant effect on bond spread. This result is not consistent with May (2010), who studies the information content of bond rating changes using daily corporate bond data in the U.S. market. May (2010)'s empirical results show that the abnormal bond returns over a two-day event window that includes the downgrade (upgrade) are negative (positive) and statistically significant. We conjecture that the insignificant statistical results regarding the effect of rating changes may be due to the lack of informational content of the ratings assigned to the subordinated bonds by Chinese CRAs.

Table 5. T-statistics of mean bond spread reaction

\begin{tabular}{|l|c|c|c|}
\hline $\begin{array}{l}\text { Mean bond spread } \\
\text { before/after the event } \\
\text { window }(-1,+1)\end{array}$ & 0.8007 & P-statistics & Significant \\
\hline $\begin{array}{l}\text { Mean bond spread } \\
\text { before/after the event } \\
\text { window }(-30,+30)\end{array}$ & 0.6176 & 0.4327 & NO \\
\hline
\end{tabular}

Lee (2006) argues that China's debt securities markets are being impeded by the lack of high quality independent credit-rating services. He claims that major Chinese credit-rating agencies have put too much emphasis on winning business by giving top ratings to most issuers, whether top ratings were deserved or not. Kennedy (2003) also suggests that these domestic rating agencies have no apparent impact on the decisions of corporate bond buyers in China and the market attaches little credibility to their ratings. We agree that there are many questions on the value of China's credit ratings to investors, despite the urgent need for high quality credit ratings in the emerging Chinese financial markets. The problems and prospects of China's credit rating industry development are discussed in the following section.

\section{Problems and Prospects of China's Credit Rating Industry Development}

Despite the rapid progress that credit ratings industry has achieved, the operations of credit ratings in China are handicapped by inefficient market infrastructure, over-regulation and 
weak supervision. Over-regulation and lack of supervision have co-existed since the debut of CRAs in China. The credit rating industry is regulated by different regulatory bodies, depending on which market that the CRA works for. Each of these bodies plays a limited, un-coordinated role in monitoring and supervision. Laws and regulations concerning credit ratings are yet to form into an effective regulatory system. At present, the regulatory framework is scattered across various financial laws, rules and regulations. The Securities Law is the only legislation enacted by the National People's Congress that regulates credit rating, but does not have well-defined provisions regarding legal status of credit ratings, legal responsibility and fairness of credit ratings and settlement of disputes between rating agencies and investors. To a large extent, the credit rating industry remains industry self-regulated; however uniform industry standards and code of conduct do not exist (Kennedy, 2004). The lack of market infrastructure and inadequate market discipline has hindered the development of the credit rating industry.

Credit ratings are largely dependent on the regulatory policy regime, rather than operating in accordance with market mechanisms. Interest rates have long been regulated by the POBC and are not fully determined by issuers and underwriters through their own consultations in the absence of intervene of the government bodies. After the Asian financial crisis, the regulatory authorities took more strict measures, requesting that all corporate bond issuers get approval from the National Development and Reform Commission (NDRC) and interest rates be subject to the ceiling imposed by the POBC: the interest rate shall not exceed 40 percent of regular savings bank deposit rates over the same period. The cap imposed on the bond interest rate cannot reflect the risk underlying a given instrument and the risk profile of the issuer. Interest rate rigidity seriously distorts bond pricing mechanism. The departure from the risk-return relationship has inevitably increased issue costs to and risk-bearing by high-quality issuers and weakened the role of bonds as an investment tool. Credit ratings perform a limited role in adjusting market supply and demands as a consequence.

Furthermore, risk controls over bond issues rely on administrative examination and approval by the government, not to be determined by the markets. The bond markets are yet open to different types of bond issuers. Issued bonds have strict vetting and security conditions, and only the companies that have acquired $\mathrm{AA}+$ grade and above are qualified for the issuance. Thus, all the listed bonds are AA+ -rated, giving rise to the "high creditability, no differentiation" phenomenon in the issuing market. No defaults on bonds have been reported since credit ratings initiated in the securities market in 1999. (Poon \& Chan, 2008) The administrative intervention to risk controls over bond issues is not conductive to the cultivation of bond market mechanism and the development of credit rating system.

CRAs have yet to establish sound and effective internal management and quality control system. Given the short history of credit ratings in China, rating methodologies, though rigorous, are yet to be systematic and subject to some form of validation based on historical experience. All assigned ratings are solicited, and, unless paid, CRAs do not routinely monitor on an ongoing basis and regularly update an analysis and a rating even when new information becomes available which needs revision or termination of the opinion. 
Quality and integrity of ratings are further handicapped by incomplete information about issuers, which is necessary for their decision-making. For instance, CRAs do not have information on the default history of the issuers they rate, as the POBC and the banks do not disclose such type of non-public information to CRAs. In addition to this, the documents that CRAs base on often contain false entries or misleading statements or have material omissions. It is difficult to guarantee that the opinions are based on a fair and thorough analysis of all relevant information available to CRAs and that the analysts perform their duties with integrity.

As a consequence of the afro-discussed market and institutional constraints, CRAs can hardly be distant from the activities and procedures that may compromise independence and objectivity, accuracy and impartiality, reliability and validity as well as transparency and standardization of credit rating operations. The independence, creditability and reliability of CRAs are being constantly questioned. Given the size of the market, inactivity in terms of trading and investor base and limited products, the demands for bond ratings are, thus, low. In order to win over business and increase their own revenues, CRAs knowingly cater to the demands of issuers and give the best ratings that money can buy (Kennedy, 2003, 2004). Issuers get their bonds rated to meet the requirements by the authorities, not for offering informed, independent analyses and opinions about their securities to investors. They shop for the best ratings from the five certified domestic CRAs until at least one of the agencies delivers a favorable rating. Credit ratings play little role in signaling to the market and influencing issuers' access to capital and the structure of financial transactions, not alone for regulatory purposes. Domestic investors and international analysts, hence, give little weight to the ratings assigned by the China's CRAs (Kennedy, 2003).

\section{Conclusion}

It has been argued that the credit ratings offered by Chinese credit rating agencies do not have information content. These criticisms are based on the fact that Chinese credit rating agencies give overly optimistic credit ratings. We examine the bond spread reaction to subordinated bond rating changes during the sample period of 2006 to 2011 and find that bond spread react positively to downgrades, big in magnitude, but not statistically significant. The bond spread reaction to upgrades, however, is mixed and statistically insignificant, and small in magnitude. We conjecture that the insignificant statistical results regarding the effect of rating changes may be due to the lack of informational content of the ratings assigned to the subordinated bonds by Chinese CRAs.

China's credit ratings are largely dependent on the regulatory policy regime, rather than operating in accordance with market mechanisms. The operations of credit ratings in China are handicapped by inefficient market infrastructure, incomplete information provided by the issuers, rating shopping behavior, and over-regulation.

\section{Acknowledgements}

The authors are grateful to Moody's Affiliate - CCXI for providing information on its rating methodology and rating data. The authors also thank the participants of 2013 Global Business, 
Economics and Finance (GBEF) Conference for providing valuable comments and constructive suggestions. Luo acknowledges a research grant from the National Social Science Foundation of China. Any remaining errors are ours.

\section{References}

Bessembinder, H., Kahle, K. M., Maxwell, W. F., \& Xu, D. (2009). Measuring abnormal bond performance. Review of Financial Studies, 22(10), 4219-4258. http://dx.doi.org/10.1093/rfs/hhn105

Bottelier, P., (2003). China's emerging domestic debt markets: facts and issues. Discussion paper for Conference on Chinese Economic Policy Reform organized by the Center for Research on Economic Development and Policy Reform, Stanford University, Palo Alto, CA September 18-20.

Dichev, I. D., \& Piotroski, J. D. (2001). The Long - Run Stock Returns Following Bond Ratings Changes. The Journal of Finance, 56(1), 173-203. http://dx.doi.org/10.1111/0022-1082.00322

Ederington, L. H., \& Goh, J. C. (1998). Bond rating agencies and stock analysts: Who knows what when? Journal of Financial and Quantitative Analysis, 33(04), 569-585. http://dx.doi.org/10.2307/2331132

Goh, J. C., \& Ederington, L. H. (1993). Is a bond rating downgrade bad news, good news, or no news for stockholders? The Journal of Finance, 48(5), 2001-2008. http://dx.doi.org/10.2307/2329078

Goh, J. C., \& Ederington, L. H. (1999). Cross-sectional variation in the stock market reaction to bond rating changes. The Quarterly Review of Economics and Finance, 39(1), 101-112. http://dx.doi.org/10.1016/S1062-9769(99)80006-4

Grier, P., \& Katz, S. (1976). The differential effects of bond rating changes among industrial and public utility bonds by maturity. Journal of Business, 226-239. http://dx.doi.org/10.1086/295833

Griffin, P. A., \& Sanvicente, A. Z. (1982). Common stock returns and rating changes: A methodological comparison. The Journal of Finance, 37(1), 103-119. http://dx.doi.org/10.2307/2327120

Hand, J. R., Holthausen, R. W., \& Leftwich, R. W. (1992). The effect of bond rating agency announcements on bond and stock prices. The Journal of Finance, 47(2), 733-752. http://dx.doi.org/10.2307/2329121

Holthausen, R. W., \& Leftwich, R. W. (1986). The effect of bond rating changes on common stock prices. Journal of Financial Economics, 17(1), 57-89. http://dx.doi.org/10.1016/0304-405X(86)90006-1

Ingram, R. W., Brooks, L. D., \& Copeland, R. M. (1983). The information content of municipal bond rating changes: A note. The Journal of Finance, 38(3), 997-1003. http://dx.doi.org/10.2307/2328094

Jorion, P., Liu, Z., \& Shi, C. (2005). Informational effects of regulation FD: evidence from rating agencies. Journal of Financial Economics, 76(2), 309-330. http://dx.doi.org/10.1016/j.jfineco.2004.05.001 
Jorion, P., \& Zhang, G. (2007). Information effects of bond rating changes: The role of the rating prior to the announcement. Journal of Fixed Income, 16, 45-59. http://dx.doi.org/10.3905/jfi.2007.683317

Katz, S. (1974). The price adjustment process of bonds to rating reclassifications: A test of bond market efficiency. The Journal of Finance, 29(2), 551-559. http://dx.doi.org/10.2307/2978826

Kennedy, S. (2003). China's credit rating agencies struggle for relevance. China Business Review, 30(6), 36-40.

Kennedy, S. (2004, March). China's languishing credit-rating industry: Canary in the mine. In 56th Annual Meeting of the Association for Asian Studies, San Diego, California.

Kim, Y., \& Nabar, S. (2007). Bankruptcy probability changes and the differential informativeness of bond upgrades and downgrades. Journal of Banking \& Finance, 31(12), 3843-3861. http://dx.doi.org/10.1016/j.jbankfin.2007.02.008

Kliger, D., \& Sarig, O. (2000). The information value of bond ratings. The Journal of Finance, 55(6), 2879-2902. http://dx.doi.org/10.1111/0022-1082.00311

Li, J., Shin, Y. S., \& Moore, W. T. (2006). Reactions of Japanese markets to changes in credit ratings by global and local agencies. Journal of Banking \& Finance, 30(3), 1007-1021. http://dx.doi.org/10.1016/j.jbankfin.2005.05.026

May, A. D. (2010). The impact of bond rating changes on corporate bond prices: New evidence from the over-the-counter market. Journal of Banking \& Finance, 34(11), 2822-2836. http://dx.doi.org/10.1016/j.jbankfin.2010.06.006

Norden, L., \& Weber, M. (2004). Informational efficiency of credit default swap and stock markets: The impact of credit rating announcements. Journal of Banking \& Finance, 28(11), 2813-2843. http://dx.doi.org/10.1016/j.jbankfin.2004.06.011

Poon, W. P., \& Chan, K. C. (2008). An empirical examination of the informational content of credit ratings in China. Journal of Business Research, 61(7), 790-797. http://dx.doi.org/10.1016/j.jbusres.2007.08.001

Sinclair, T. J. (2014). The new masters of capital: American bond rating agencies and the politics of creditworthiness. Cornell University Press.

Wansley, J. W., \& Clauretie, T. M. (1985). The impact of creditwatch placement on equity returns and bond prices. Journal of Financial Research, 8(1), 31-42. http://dx.doi.org/10.1111/j.1475-6803.1985.tb00423.x

Weinstein, M. I. (1977). The effect of a rating change announcement on bond price. Journal of Financial Economics, $329-350$. http://dx.doi.org/10.1016/0304-405X(77)90042-3

\section{Note}

Note 1. The joint venture is considered as a co-operation between the largest domestic rating agency and the most respectable international rating agency and has turned a new page of Chinese capital market and credit rating industry. Built on their 20 years' credit rating 


\section{Macrothink}

practice and unique understanding on the domestic companies and business environment, the entry of Moody's helps CCXI to enhance rating methodologies and techniques and adopt the international rating standards to conduct higher quality credit ratings.

\section{Copyright Disclaimer}

Copyright for this article is retained by the author(s), with first publication rights granted to the journal. This is an open-access article distributed under the terms and conditions of the Creative Commons Attribution license (http://creativecommons.org/licenses/by/3.0/). 